\title{
DETERMINANTY KSZTALTOWANIA POLSKIEGO BEZPIECZEŃSTWA GOSPODARCZEGO. WYBRANE ASPEKTY
}

Wśród ważnych dziedzin bezpieczeństwa narodowego wymienia się bezpieczeństwo gospodarcze. Warunkiem rozwoju współczesnych państw i społeczeństw jest właściwe kształtowanie bezpieczeństwa gospodarczego. Skuteczność i efektywność kształtowania bezpieczeństwa gospodarczego zależy w znacznym stopniu od racjonalnego rozpoznania i wykorzystania wielu zmiennych w czasie i przestrzeni determinant. Celem artykułu jest przybliżenie determinant kształtowania polskiego bezpieczeństwa gospodarczego w kontekście wybranych aspektów teoretycznych i praktycznych.

W pracy opisano istotę bezpieczeństwa gospodarczego. Przedstawiono pojęcie i rodzaje determinant tego bezpieczeństwa w ujęciu teoretycznym, w tym zaproponowano własną klasyfikację determinant bezpieczeństwa gospodarczego. Zwrócono uwagę na makroekonomiczne determinanty polskiego bezpieczeństwa gospodarczego. Przeanalizowano wyniki „Narodowego Programu Foresight Polska 2020” w aspekcie determinant kształtowania polskiego bezpieczeństwa gospodarczego. Zaprezentowano zapisy „Strategii Bezpieczeństwa Narodowego RP” dotyczące bezpieczeństwa gospodarczego.

\section{ISTOTA BEZPIECZEŃSTWA GOSPODARCZEGO}

Ważnym rodzajem bezpieczeństwa jest bezpieczeństwo gospodarcze, nazywane również bezpieczeństwem ekonomicznym. W ramach ogólnego bezpieczeństwa, z punktu widzenia dziedziny w jakiej występuje, wyodrębnia się obok bezpieczeństwa gospodarczego między innymi następujące rodzaje bezpieczeństwa: militarne, polityczne, ekologiczne, społeczne, kulturowe, informacyjne. Warto podkreślić, że bezpieczeństwo wymienia się wśród podstawowych funkcji państwa i uznaje się za dobro publiczne stanowiące przesłankę dla interwencjonizmu władz publicznych.

Definicje bezpieczeństwa gospodarczego (ekonomicznego) przedstawiono w literaturze przedmiotu. Najogólniej bezpieczeństwo gospodarcze można określić jako stan, w którym nie ma zagrożeń ${ }^{1}$. Jednocześnie bezpieczeństwo ekonomiczne definiuje się jako całokształt czynników i uwarunkowań zabezpieczających niezależność gospo-

1 Por. K. Żukrowska, Pojęcie bezpieczeństwa i jego ewolucja, w: Bezpieczeństwo międzynarodowe. Teoria i praktyka, red. K. Żukrowska, M. Grącik, Szkoła Główna Handlowa, Warszawa 2006, s. 21. 
darki narodowej, stabilność oraz zrównoważenie, gwarantujących jej doskonalenie $\mathrm{się}^{2}$. Natomiast rozważania w książce E. Frejtag-Miki, Z. Kołodziejaka, W. Putkiewicza, Bezpieczeństwo ekonomiczne we współczesnym świecie, prowadzą do następującej konstatacji: ,bezpieczeństwo ekonomiczne jest to zdolność systemu gospodarczego państwa (grupy państw) do takiego wykorzystania wewnętrznych czynników rozwoju i międzynarodowej współzależności ekonomicznej, które będą gwarantowały jego niezagrożony rozwój"3.

Wyodrębnia się różne rodzaje bezpieczeństwa gospodarczego. Wydziela się między innymi bezpieczeństwa gospodarcze: globalne, międzynarodowe, regionalne, narodowe. Jednocześnie można analizować bezpieczeństwo wewnętrzne i zewnętrzne. Według kryterium przedmiotowego (sektorowo-branżowego, dziedzinowego) w ramach bezpieczeństwa gospodarczego prowadzi się rozważania dotyczące takich rodzajów bezpieczeństwa jak: rolne i żywnościowe, przemysłowe, transportowe, surowcowe i energetyczne, finansowe, budżetowe, walutowe. Zgodnie z tym kryterium można wyróżnić także bezpieczeństwo w dziedzinie kapitału ludzkiego, które rozpatruje między innymi wykorzystanie kapitału ludzkiego i wpływ migracji na funkcjonowanie gospodarki ${ }^{4}$.

Tabela 1 zawiera kompleksową koncepcję prezentującą zarys systematyki bezpieczeństwa ekonomicznego.

Tabela 1

Zarys systematyki bezpieczeństwa ekonomicznego

\begin{tabular}{||c|l||}
\hline $\begin{array}{c}\text { Kryterium } \\
\text { wyróżnienia }\end{array}$ & \multicolumn{1}{|c|}{ Zakres (wymiar) treści pojęcia ,bezpieczeństwo ekonomiczne” } \\
\hline 1 & \multicolumn{1}{|c||}{2} \\
\hline Zakres pojęciowy & $\begin{array}{l}\text { 1. Tradycyjne BE - pochodne problemów politycznych i militarnych, określane w tym } \\
\text { ujęciu jako ,ekonomiczne aspekty bezpieczeństwa” (podatnośc kraju na przeniesienie } \\
\text { przez płaszczyznę gospodarcza, działań gospodarczych o charakterze politycznym, skie- } \\
\text { rowanych na osłabienie bezpieczeństwa kraju). } \\
\text { 2. Współczesne - rozszerzanie BE poza kwestie obronno-ekonomiczne i nadawanie pod- } \\
\text { stawowej i względnie samodzielnej rangi kwestiom bezpieczeństwa gospodarki (takie } \\
\text { wykorzystanie wewnętrznych czynników rozwoju i międzynarodowej współzależności } \\
\text { ekonomicznej, które będą gwarantowały niezagrożony rozwój). }\end{array}$ \\
\hline Płaszczyzny & $\begin{array}{l}\text { 1. Ogólnoekonomiczna (społeczno-ekonomiczna). } \\
\text { 2. Obronno-ekonomiczna (wojenno-ekonomiczna). }\end{array}$ \\
\hline Forma & $\begin{array}{l}\text { 1. Przedmiotowe - surowcowe, finansowe, technologiczne, rolne, żywnościowe itp. } \\
\text { 2. Podmiotowe - współzależności, zależności, siła i trwałość powiązan. }\end{array}$ \\
\hline
\end{tabular}

${ }^{2}$ K. A. Kłosiński, Światowe determinanty bezpieczeństwa ekonomicznego, w: Bezpieczeństwo ekonomiczne państw, red. T. Guz, K. A. Kłosiński, P. Marzec, Katolicki Uniwersytet Lubelski, Lublin 2006, s. 41.

${ }^{3}$ http://www.bezpieczenstwoekonomiczne.pl/definicja.htm; strona internetowa dr. Krzysztofa Księżopolskiego (28.12.2010); zob. E. Frejtag-Mika, Z. Kołodziejak, W. Putkiewicz, Bezpieczeństwo ekonomiczne we wspótczesnym świecie, Politechnika Radomska, Radom 1996; K. Księżopolski, Ekonomiczne zagrożenia bezpieczeństwa państw. Metody i środki przeciwdziałania, Elipsa, Warszawa 2004

${ }^{4}$ Zob. I. Jaźwiński, Bezpieczeństwo gospodarcze w aspekcie kapitału ludzkiego, referat na ogólnopolską konferencję ,Z tarczą czy na tarczy? Bezpieczeństwo Polski a Polska w bezpiecznym świecie”, Uniwersytet Szczeciński, Szczecin, kwiecień 2008. 


\begin{tabular}{|c|c|}
\hline 1 & 2 \\
\hline $\begin{array}{l}\text { Podmiot } \\
\text { (przestrzeń) }\end{array}$ & $\begin{array}{l}\text { 1. Państwa. } \\
\text { 2. Grupy państw (ugrupowania, regionu). } \\
\text { 3. Globalne. }\end{array}$ \\
\hline Czas & $\begin{array}{l}\text { 1. Stan. } \\
\text { 2. Proces. }\end{array}$ \\
\hline $\begin{array}{l}\text { Intensywność ogra- } \\
\text { niczeń i sprzeczności }\end{array}$ & $\begin{array}{l}\text { 1. Stan gospodarki, w którym zapewniono zaspokojenie podstawowych potrzeb. } \\
\text { 2. Proces zapewniający przetrwanie i rozwój systemu gospodarczego w sytuacji zagrożenia. } \\
\text { 3. Sytuacja, w której sprzeczności (wewnątrz- i międzysystemowe) nie prowadzą do } \\
\text { wystapienia zagrożeń, konfliktów i kryzysów. }\end{array}$ \\
\hline $\begin{array}{l}\text { Zakres realizowa- } \\
\text { nych wartości }\end{array}$ & $\begin{array}{l}\text { 1. Pozytywne-zespół właściwości gospodarki narodowej, o której możemy orzekać, że } \\
\text { trwa i się rozwija (rozwój, dobrobyt). } \\
\text { 2. Negatywne-przetrwanie, ochrona osiąniętego poziomu rozwoju i pozycji w układzie } \\
\text { międzynarodowym. }\end{array}$ \\
\hline $\begin{array}{l}\text { Wymiar (relacje } \\
\text { z otoczeniem) }\end{array}$ & $\begin{array}{l}\text { 1. Wewnętrzne - efektywne wykorzystanie wewnętrznych czynników rozwoju, zgodnie } \\
\text { z preferencjami społeczeństwa (hierarchią wartości). } \\
\text { 2. Zewnętrzne - brak zagrożeń zewnętrznych, wykorzystanie współzależności gospodar- } \\
\text { czych i zasobów zewnętrznych do przyspieszenia rozwoju i realizacji racji stanu państwa. }\end{array}$ \\
\hline Cechy wyróżniające & $\begin{array}{l}\text { 1. Nie można sformułować w stosunku do pozytywnego bezpieczeństwa ekonomicznego } \\
\text { warunku wystarczalności. } \\
\text { 2. Znaczenie podstawowe mają wewnętrzne czynniki rozwoju. } \\
\text { 3. Bezpieczeństwo ekonomiczne budują adaptacyjność i podatność na zmiany, a nie stabi- } \\
\text { lizacja. } \\
\text { 4. Sprzeczności między potrzebną współzależnością, warunkującą efektywność i posze- } \\
\text { rzanie rynków, a uzależnieniem zewnętrznym gospodarki. } \\
\text { 5. Ograniczona rola państwa w kształtowaniu bezpieczeństwa ekonomicznego. }\end{array}$ \\
\hline Sposób realizacji & $\begin{array}{l}\text { 1. Indywidualne. } \\
\text { 2. Integracja. } \\
\text { 3. Współpraca. }\end{array}$ \\
\hline
\end{tabular}

Źródło: Podstawy, mechanizmy i procedury ksztaltowania bezpieczeństwa ekonomicznego Polski z punktu widzenia narodowej i sojuszniczej strategii obronnej. Kryptonim „PMP-BENSSO”, cz. 1: Metodologia i model badań bezpieczeństwa ekonomicznego kraju, red. Z. Stachowiak, AON, Warszawa 2001, s. 59, za: Bezpieczeństwo ekonomiczne Rzeczypospolitej Polskiej, AON, Warszawa 2003, s. 34-35.

Istotne jest racjonalne prowadzenie polityki publicznej w dziedzinie bezpieczeństwa gospodarczego i właściwe kształtowanie jej poszczególnych elementów w układzie morfologicznym. Polityka ta jest częścią polityki publicznej i w znacznym stopniu zawiera się w polityce gospodarczej. Elementami każdej polityki, w tym polityki kształtującej bezpieczeństwo gospodarcze, w układzie morfologicznym są: jej podmioty i przedmiot, cele i zadania, determinanty (uwarunkowania), zasady, narzędzia i instrumenty, efekty (rezultaty).

\section{POJĘCIE I RODZAJE DETERMINANT BEZPIECZEŃSTWA GOSPODARCZEGO W UJĘCIU TEORETYCZNYM}

Determinanty bezpieczeństwa gospodarczego to czynniki, które w sposób istotny wpływają na to bezpieczeństwo. Kategorią analogiczną i bliskoznaczną w stosunku do pojęcia „determinanty bezpieczeństwa gospodarczego” jest termin ,uwarunkowania bezpieczeństwa gospodarczego". Przyjmować można przynajmniej dwa podejścia 
przy określaniu relacji między tymi pojęciami. Według pierwszego podejścia determinanty uznaje się za szczególnie istotne uwarunkowania - decydujące i przesądzające w kształtowaniu bezpieczeństwa. Zgodnie z drugim podejściem dwa wymienione pojęcia traktuje się jako równorzędne, tożsame.

Skuteczność i efektywność kształtowania bezpieczeństwa gospodarczego zależy w znacznym stopniu od racjonalnego rozpoznania i wykorzystania wielu zmiennych w czasie i przestrzeni determinant (uwarunkowań). Ważne jest, aby polityka publiczna w dziedzinie bezpieczeństwa gospodarczego była nakierowana na rozpoznanie, pozytywne (współ)kształtowanie determinant oraz neutralizowanie (eliminowanie) lub ograniczanie determinant niekorzystnych. Determinanty tworzą ramy dla prowadzenia polityki w dziedzinie bezpieczeństwa gospodarczego, wpływając między innymi na cele i kierunki oraz narzędzia i instrumenty tej polityki. Przyjmuje się, że w danym momencie determinanty są zmienną niezależną, którą należy uwzględniać, w dłuższym okresie mogą stanowić przedmiot oddziaływań.

Determinanty bezpieczeństwa gospodarczego klasyfikuje się w oparciu o różne kryteria. Rodzaje determinant w ujęciu teoretycznym wyodrębnione ze względu na określone kryteria zaprezentowano w tabeli 2 . Wydzielać można między innymi determinanty wewnętrzne i zewnętrzne, nazywane często endogenicznymi i egzogenicznymi.

Klasyfikacja determinant bezpieczeństwa gospodarczego

\begin{tabular}{|c|c|}
\hline Kryterium & Rodzaje determinant \\
\hline 1 & 2 \\
\hline \multirow[t]{4}{*}{ Źródło (pochodzenie) } & $\begin{array}{l}\text { - wewnętrzne } \\
\text { - zewnętrzne }\end{array}$ \\
\hline & $\begin{array}{l}\text { - endogeniczne (pochodzące z wewnątrz) } \\
\text { - egzogeniczne (pochodzące z zewnątrz) }\end{array}$ \\
\hline & $\begin{array}{l}\text { - własne } \\
\text { - obce }\end{array}$ \\
\hline & $\begin{array}{l}\text { - polityczne } \\
\text { - prawne } \\
\text { - militarne } \\
\text { - technologiczne } \\
\text { - ekonomiczne } \\
\text { - społeczne } \\
\text { - kulturowe } \\
\text { - ekologiczne } \\
\text { - geograficzne } \\
\text { - inne }\end{array}$ \\
\hline \multirow[t]{2}{*}{ Zasięg (skala) oddziaływania } & $\begin{array}{l}\text { - międzynarodowe } \\
\text { - krajowe } \\
\text { - regionalne } \\
\text { - lokalne }\end{array}$ \\
\hline & $\begin{array}{l}\text { - megaekonomiczne } \\
\text { - makroekonomiczne } \\
\text { - mezoekonomiczne } \\
\text { - mikroekonomiczne }\end{array}$ \\
\hline
\end{tabular}




\begin{tabular}{|c|c|}
\hline 1 & 2 \\
\hline Przedmiotowe & $\begin{array}{l}\text { - rolne i żywnościowe } \\
\text { - przemysłowe } \\
\text { - transportowe } \\
\text { - surowcowe i energetyczne } \\
\text { - finansowe } \\
\text { - budżetowe } \\
\text { - walutowe } \\
\text { - inne }\end{array}$ \\
\hline \multirow[t]{2}{*}{ Charakter } & $\begin{array}{l}\text { - wspólne (ogólne) } \\
\text { - specyficzne (odrębne) }\end{array}$ \\
\hline & $\begin{array}{l}\text { - ilościowe } \\
\text { - jakościowe }\end{array}$ \\
\hline Sprzyjanie bezpieczeństwu & $\begin{array}{l}\text { - sprzyjające } \\
\text { - neutralne } \\
\text { - niesprzyjające (zagrożenia) }\end{array}$ \\
\hline Możliwość kształtowania & $\begin{array}{l}\text { - kształtowalne } \\
\text { - częściowo kształtowalne } \\
\text { - niekształtowalne }\end{array}$ \\
\hline Rozpoznanie & $\begin{array}{l}\text { - rozpoznane } \\
\text { - częściowo rozpoznane } \\
\text { - nierozpoznane }\end{array}$ \\
\hline Ranga (waga) & $\begin{array}{l}\text { - o dużej randze (najważniejsze) } \\
\text { - o przeciętnej randze } \\
\text { - o małej randze }\end{array}$ \\
\hline \multirow[t]{2}{*}{$\begin{array}{l}\text { Dynamika, zmiany (w ujęciach } \\
\text { względnym i bezwzględnym) }\end{array}$} & $\begin{array}{l}\text { - o rosnącym znaczeniu } \\
\text { - o niezmieniającym się znaczeniu } \\
\text { - o malejącym znaczeniu }\end{array}$ \\
\hline & $\begin{array}{l}\text { - zmieniające się szybko } \\
\text { - zmieniające się powoli } \\
\text { - niezmieniające się, stabilne (w danym okresie) }\end{array}$ \\
\hline
\end{tabular}

Źródło: Opracowanie własne.

Za ważne determinanty bezpieczeństwa gospodarczego można uznać również główne uwarunkowania polityki ekonomicznej określone przez B. Winiarskiego ${ }^{5}$, do których zalicza się warunkowania:

- ustrojowo-systemowe:

- ustrój polityczno-społeczny - ogół zasad, szczególnie prawnych, określających ogólnie organizację i sposób funkcjonowania państwa,

- system ekonomiczny ${ }^{6}$ - zbiór powszechnie obowiązujących norm prawnych i ogólnie akceptowanych zasad regulujących postępowanie uczestników procesu gospodarczego;

- zewnętrzne:

- międzynarodowa sytuacja polityczna, stosunki z sąsiadami,

- przynależność do międzynarodowych ugrupowań (organizacji) politycznych, militarnych, gospodarczych,

5 B. Winiarski, Uwarunkowania, cele i dziedziny polityki gospodarczej, w: Polityka gospodar$c z a$, red. B. Winiarski, PWN, Warszawa 2004, s. 64.

6 Ibidem, s. 31-32. 
- międzynarodowa sytuacja gospodarcza,

- warunki wymiany (terms of trade);

- wewnętrzne:

- stan i struktura zasobów przyrodniczych, majątkowych i ludzkich,

- zagospodarowanie przestrzenne kraju i regionów,

- wewnętrzna sytuacja polityczna,

- stosunki narodowościowe,

- stosunek społeczeństwa do władzy,

- układ sił politycznych w kraju.

Rola i znaczenie poszczególnych determinant bezpieczeństwa gospodarczego oraz ich grup zmienia się w czasie i kolejnych fazach rozwoju. Przykładowo w warunkach globalizacji i integracji europejskiej wzrosło znaczenie uwarunkowań o charakterze międzynarodowym. Zagadnieniem kluczowym w kształtowaniu bezpieczeństwa gospodarczego jest właściwe rozpoznanie jego determinant oraz koncentracja środków (zasobów) i narzędzi (instrumentów) na odpowiednio wybranych determinantach, w tym zwłaszcza na determinantach kształtowalnych, o dużej randze i rosnącym znaczeniu.

\section{WYBRANE MAKROEKONOMICZNE DETERMINANTY KSZTALTOWANIA BEZPIECZEŃSTWA GOSPODARCZEGO}

W procesie kształtowania bezpieczeństwa gospodarczego powinno zwracać się szczególną uwagę na determinanty makroekonomiczne. Sytuacja makroekonomiczna należy do ważnych czynników oddziałujących na bezpieczeństwo państwa. Jednocześnie bezpieczeństwo gospodarcze kraju jest w znacznym stopniu determinowane przez uwarunkowania międzynarodowe, w tym o charakterze makroekonomicznym. Warto podkreślić, że problematyka makroekonomiczna została szeroko przedstawiona w literaturze. Jednak stosunkowo rzadziej bywa rozważana w interdyscyplinarnym aspekcie bezpieczeństwa narodowego.

Korzystna sytuacja makroekonomiczna tworzy sprzyjające podstawy dla funkcjonowania społeczeństw i gospodarek oraz rozwoju społeczno-gospodarczego. Makroekonomiczne determinanty decydują o możliwości realizacji stabilizacyjnej funkcji państwa, służącej zapewnieniu, aby gospodarka pozostawała w stanie pełnego zatrudnienia przy stabilnych cenach. Na bezpieczeństwo gospodarcze wpływają różne czynniki makroekonomiczne o charakterze krajowym i międzynarodowym, w tym budżetowe, pieniężne i rynku pracy. Wśród czynników budżetowych można wymienić przede wszystkim dług publiczny, deficyt budżetowy i strukturę wydatków budżetowych. W ramach czynników pieniężnych można uwzględniać inflację i kurs walutowy. Natomiast do czynników rynku pracy zalicza się przede wszystkim bezrobocie i aktywność zawodową społeczeństwa.

$\mathrm{Z}$ punktu widzenia kształtowania determinant bezpieczeństwa gospodarczego w aspekcie makroekonomicznym istotna jest realizacja celów tworzących magiczny czworokąt celów polityki gospodarczej, którymi są:

- wzrost i rozwój gospodarczy (zrównoważony);

- wysoki poziom zatrudnienia;

- stabilność cen; 
- równowaga w stosunkach gospodarczych z zagranicą.

Układ wymienionych celów można rozszerzać, uwzględniając kolejne cele, np. takie jak równowaga budżetowa, racjonalny poziom długu publicznego. Według OECD realizacja celów magicznego czworokąta polityki gospodarczej może oznaczać jednoczesne osiaganie ${ }^{7}: 3 \%$ realnego wzrostu gospodarczego, $5 \%$ stopy bezrobocia; $2 \%$ stopy inflacji.

Bezpieczeństwu gospodarczemu sprzyja racjonalne prowadzenie polityki makroekonomicznej, w tym polityk budżetowej i pieniężnej. Polityka budżetowa polega na kształtowaniu wielkości i struktury dochodów i wydatków budżetowych. Ważne jest, aby respektując preferencje i potrzeby społeczne oraz możliwości i rozwój gospodarki dążyć do optymalnego ukształtowania:

- wielkości budżetu w stosunku do dochodu narodowego (PKB);

- struktury dochodów i wydatków budżetowych z uwzględnieniem dążenia do osiagnięcia znacznego udziału wydatków na zadania rozwojowe.

Polityka pieniężna polega na oddziaływaniu na podaż pieniądza. Cel nadrzędny tej polityki za W. Wilczyńskim można określić jako „tworzenie warunków sprzyjających racjonalnemu gospodarowaniu wszystkich podmiotów gospodarczych i osób fizycznych przez stabilizację pieniądza”. Autor ten podkreśla, że „polityka pieniężna kształtując podaż pieniądza, jego zasoby w gospodarce powinna przestrzegać swoistych warunków brzegowych. Podaż pieniądza nie powinna być tak mała, by uniemożliwiać podejmowanie racjonalnych przedsięwzięć gospodarczych (dolny warunek brzegowy). Z drugiej strony podaż pieniądza nie powinna być tak wielka, by grozić uruchomieniem się samonapędzającej się inflacji (górny warunek brzegowy)"”.

Wydaje się, że do ważnych zagrożeń dla polskiego bezpieczeństwa gospodarczego $\mathrm{w}$ aspekcie makroekonomicznym można zaliczyć:

- przenikające z zagranicy skutki światowych i międzynarodowych kryzysów gospodarczych i finansowych;

- narastanie długu publicznego;

- spadek tempa przyrostu PKB;

- niewykorzystywanie kapitału ludzkiego;

- niestabilność poziomu cen;

- niekorzystne zmiany kursów walutowych.

\section{DETERMINANTY KSZTALTOWANIA POLSKIEGO BEZPIECZEŃSTWA GOSPODARCZEGO W ŚWIETLE WYNIKÓW NARODOWEGO PROGRAMU FORESIGHT}

Rozważania dotyczące determinant kształtowania polskiego bezpieczeństwa gospodarczego mogą być również prowadzone w aspekcie wyników „Narodowego Pro-

7 A. Slany, Stosowana polityka gospodarcza, Wyższa Szkoła Zarządzania we Wrocławiu, Wrocław 2004, s. 13-14.

8 W. Wilczyński, Rynek i pieniq̨dz w Polsce u progu XXI wieku, Wyższa Szkoła Bankowa, Poznań 2000, s. 114.

9 Ibidem, s. 109. 
gramu Foresight Polska 2020"10, w którym dużą uwagę zwrócono na problematykę bezpieczeństwa, w tym bezpieczeństwa gospodarczego. Do najważniejszych celów tego programu zaliczono określenie wizji rozwojowej Polski do 2020 roku oraz określenie priorytetowych kierunków badań naukowych i prac rozwojowych, które w wieloletniej perspektywie wpłyną na przyspieszenie tempa rozwoju społeczno-gospodarczego. Badania typu foresight służą racjonalnemu przewidywaniu przyszłości. Realizacji projektu podjęło się konsorcjum złożone z Instytutu Podstawowych Problemów Techniki PAN, Pentor Research International oraz Instytutu Nauk Ekonomicznych PAN. Program został uruchomiony w 2006 roku i w jego ramach kilka tysięcy ekspertów ze wszystkich sfer życia naukowego i społecznego przez kilkanaście miesięcy zastanawiało się nad sposobami zapewnienia Polsce trwałego rozwoju, którego celem będzie rosnąca jakość życia społeczeństwa.

Podczas realizacji „Narodowego Programu Foresight Polska 2020” wykorzystano następujące metody badawcze: analizę Delphi, analizę PEST (analizę czynników politycznych, ekonomicznych, społecznych i technologicznych), krzyżową analizę wpływów. Warto podkreślić, że określono listę czynników kluczowych, które będą determinowały rozwój w perspektywie roku 2020 i jednocześnie stanowić będą źródło niepewności. Do tych czynników zaliczono: modernizację polskich instytucji publicznych (reformy wewnętrzne), trendy rozwoju świata i Europy (otoczenie zewnętrzne), gospodarkę opartą na wiedzy (potencjał kadrowy i naukowo-badawczy, produkcja i transfer wiedzy do gospodarki i społeczeństwa, innowacyjność), legitymizację polityki rozwojowej (bilans społecznych, środowiskowych, ekonomicznych kosztów modernizacji i poziom akceptacji społecznej).

Wydzielono trzy Pola Badawcze: „Zrównoważony rozwój Polski”, „Technologie informacyjne i telekomunikacyjne”, „Bezpieczeństwo”. Każde z tych trzech Pól Badawczych zostało podzielone na Tematy. W ramach Pola „Bezpieczeństwo” określono następujące tematy:

- bezpieczeństwo ekonomiczne (zewnętrzne i wewnętrzne);

- bezpieczeństwo intelektualne;

- bezpieczeństwo socjalne;

- bezpieczeństwo techniczno-technologiczne;

- rozwój społeczeństwa obywatelskiego.

W trakcie prac w ramach Tematu „Bezpieczeństwo ekonomiczne” wyodrębniono następujące makropriorytety ${ }^{11}$ : zmiany układu sił $\mathrm{w}$ gospodarce światowej, rozwój i wykorzystanie kapitału ludzkiego, luka technologiczna, Polska w UE, dostępność i wykorzystanie surowców mineralnych ze szczególnym uwzględnieniem surowców energetycznych, system finansowy w Polsce, zmiany strukturalne w polskiej gospodarce (struktura sektorowa i własnościowa). W tabeli 3 przedstawiono najważniejsze dziedziny wpływu czynników kluczowych na zrównoważony rozwój Polski w temacie „Bezpieczeństwo ekonomiczne”.

10 Wyniki Narodowego Programu Foresight Polska 2020, Warszawa, czerwiec 2009.

11 Ibidem, s. 161. 
Dziedziny wpływu czynników kluczowych na zrównoważony rozwój Polski w temacie „Bezpieczeństwo ekonomiczne”

\begin{tabular}{|c|c|}
\hline Reformy wewnętrzne & Otoczenie zewnętrzne \\
\hline $\begin{array}{l}\text { - zdolność do absorpcji zmian demograficznych } \\
\text { (zwłaszcza starzenie się społeczeństwa); } \\
\text { - skala, charakter, efekty ekonomiczne migracji (z i do } \\
\text { Polski); } \\
\text { - skala poprawy systemu edukacyjnego i rozwoju ka- } \\
\text { pitału ludzkiego; } \\
\text { - skala poprawy stanu infrastruktury; } \\
\text { - stopień bezpieczeństwa energetycznego (bezpieczeń- } \\
\text { stwa dostaw, kosztów energii); } \\
\text { - skala redukcji luki technologicznej; } \\
\text { - zmiana poziomu innowacyjności polskiej gospo- } \\
\text { darki; } \\
\text { - zdolność do przeciwstawienia się zjawiskom kryzy- } \\
\text { sowym w dziedzinie finansów (publicznych i pry- } \\
\text { watnych) }\end{array}$ & $\begin{array}{l}\text { - } \text { rola Polski w gospodarce światowej; } \\
\text { - rola Polski w Unii Europejskiej (w tym dostępność } \\
\text { i skala środków rozwojowych z budżetu UE); } \\
\text { - dostępność kapitału i tempo procesów moderniza- } \\
\text { cyjnych; } \\
\text { - skala, charakter, efekty ekonomiczne migracji (z i do } \\
\text { Polski); } \\
\text { - szanse zapewnienia bezpieczeństwa energetycznego; } \\
\text { - zdolność do przeciwstawienia się zjawiskom kryzy- } \\
\text { sowym w dziedzinie finansów }\end{array}$ \\
\hline
\end{tabular}

Źródło: Wyniki Narodowego Programu Foresight Polska 2020, Warszawa, czerwiec 2009, s. 225.

Przedstawione w tabeli 3 dziedziny mogą być użyteczne w procesie analizy zewnętrznych i wewnętrznych determinant polskiego bezpieczeństwa gospodarczego.

W ramach Narodowego Programu Foresight sformułowano również rekomendacje w obszarze „Bezpieczeństwo”, zwracając uwagę na następujące niedostatecznie rozpoznane obszary badawcze ${ }^{12}$ :

- zjawiska rozwoju gospodarki opartej na wiedzy i innowacji na poziomie przedsiębiorstw (mikro) oraz całej gospodarki (makro);

- bariery dla przedsiębiorczości, innowacyjności i gospodarki opartej na wiedzy;

- modele wzrostu gospodarczego, a w szczególności wzrostu opartego na klasycznych inwestycjach kapitałowych i wzrostu opartego na wiedzy;

- procesy redukcji luki technologicznej w oparciu o import technologii (model dalekowschodni z lat 1960. i 1970.) i o rozwój własnego sektora B+R;

- zjawiska związane ze starzeniem się społeczeństwa (konsekwencji dla systemów emerytalnych, służby zdrowia, rynku pracy);

- wpływ zmian instytucjonalnych na funkcjonowanie gospodarki polskiej;

- proces reform finansów publicznych i związki pomiędzy skalą i strukturą wydatków a rozwojem gospodarczym Polski;

- społeczne implikacje procesów głębokich reform gospodarczych;

- zmiany funkcjonowania UE i możliwe strategie działania Polski w procesie reform Unii. 


\section{DETERMINANTY KSZTALTOWANIA POLSKIEGO BEZPIECZEŃSTWA GOSPODARCZEGO W ŚWIETLE STRATEGII BEZPIECZEŃSTWA NARODOWEGO}

Analizy dotyczące determinant kształtowania polskiego bezpieczeństwa gospodarczego powinny uwzględniać zapisy „Strategii Bezpieczeństwa Narodowego Rzeczypospolitej Polskiej"13, zatwierdzonej w listopadzie 2007 roku. Strategia wyznacza kierunki polskiej polityki publicznej w dziedzinie bezpieczeństwa narodowego. Dokument ten wydano w oparciu o art. 4a ust. 1, pkt 1 ustawy z 21 listopada 1967 roku o powszechnym obowiązku obrony Rzeczpospolitej Polskiej.

W strategii znaczną uwagę zwrócono na problematykę bezpieczeństwa gospodarczego. W części zatytułowanej „Uwarunkowania bezpieczeństwa narodowego Rzeczypospolitej Polskiej” zauważono, że „wzrasta znaczenie ekonomicznego wymiaru bezpieczeństwa, zwłaszcza bezpieczeństwa energetycznego"14. Analizując wyzwania i zagrożenia bezpieczeństwa zaakcentowano, iż „w perspektywie długofalowej bezpieczeństwo Polski w znacznej mierze zależy od zdolności państwa do stawienia czoła wyzwaniom, które wykraczają poza tradycyjnie rozumiane zagrożenia bezpieczeństwa. Wyzwania te są konsekwencją sprzężonych ze sobą procesów politycznych, ekonomiczno-społecznych, demograficznych i ekologicznych [...]"15. W tym kontekście między innymi stwierdzono, że:

- „niepokój budzą zmiany demograficzne w Polsce, a szczególnie charakter i skala migracji z Polski do innych państw w poszukiwaniu pracy i lepszych warunków życia, a także malejący przyrost naturalny i w konsekwencji starzenie się społeczeństwa. Długofalowo spowoduje to niekorzystne przekształcenia struktury społecznej, które mogą prowadzić do załamania systemu emerytalnego"16;

- ,poziom zintegrowania światowego życia ekonomicznego oraz rynków finansowych powoduje, iż gwałtowne zmiany i kryzysy zachodzące nie tylko w najbliższym otoczeniu Polski, ale i w innych rejonach świata, mogą oddziaływać negatywnie na stabilność, konkurencyjność i możliwości rozwojowe polskiej gospodarki, a tym samym i bezpieczeństwo państwa"17.

Warto podkreślić, że „Strategia Bezpieczeństwa Narodowego RP” obejmuje oddzielny podrozdział zatytułowany „Bezpieczeństwo ekonomiczne”, w którym ujęto zagadnienia dotyczące między innymi energetyki, finansów, przemysłowego potencjału obronnego, infrastruktury transportowej i łączności. Zwrócono uwagę, że „bezpieczeństwo państwa oraz jego stabilność muszą mieć trwałe podstawy gospodarcze. Silna i konkurencyjna gospodarka to jeden z podstawowych atutów w polityce wewnętrznej i zewnętrznej, a także czynnik służący umacnianiu narodowej tożsamości. [...] rozwijająca się w szybkim tempie polska gospodarka decyduje o międzynarodowej pozycji państwa" ${ }^{\prime 18}$. W aspekcie makroekonomicznym stwierdzono, iż „polityka budżetowa w zakresie finansów publicznych

\footnotetext{
13 Strategia Bezpieczeństwa Narodowego Rzeczypospolitej Polskiej, Warszawa 2007.

14 Ibidem, s. 7.

15 Ibidem, s. 8.

16 Ibidem, s. 8.

17 Ibidem, s. 9.

18 Ibidem, s. 17.
} 
zapewni stabilność nakładów na wydatki związane z zagwarantowaniem bezpieczeństwa narodowego oraz trwałego rozwoju gospodarczego. Wymaga to przede wszystkim utrzymania równowagi budżetowej oraz zadłużenia wewnętrznego i zagranicznego na odpowiednim, bezpiecznym poziomie" ${ }^{\text {"19 }}$.

$$
* * *
$$

Bezpieczeństwo gospodarcze powinno być postrzegane jako jedna z kluczowych dziedzin bezpieczeństwa narodowego Polski. Ważną kwestią w kształtowaniu polskiego bezpieczeństwa gospodarczego jest właściwe rozpoznanie jego determinant oraz koncentracja środków i narzędzi na odpowiednio wybranych determinantach, w tym zwłaszcza na determinantach kształtowalnych, o dużej randze i rosnącym znaczeniu. W tych procesach warto uwzględniać typologię determinant bezpieczeństwa gospodarczego. Podstawą bezpieczeństwa narodowego i gospodarczego jest wysoki poziom bezpieczeństwa makroekonomicznego związany ze stabilnością gospodarki. Determinanty kształtowania polskiego bezpieczeństwa gospodarczego mogą być analizowane w świetle wyników „Narodowego Programu Foresight Polska 2020” i zapisów dokumentów programowych polityki bezpieczeństwa narodowego. Korzystne jest, że w ważnym dokumencie tej polityki „Strategii Bezpieczeństwa Narodowego RP” deklaruje się przywiązywanie dużej wagi do bezpieczeństwa ekonomicznego.

\title{
STRESZCZENIE
}

Warunkiem rozwoju współczesnych państw i społeczeństw jest właściwe kształtowanie bezpieczeństwa gospodarczego. Skuteczność i efektywność kształtowania bezpieczeństwa gospodarczego zależy w znacznym stopniu od racjonalnego rozpoznania i wykorzystania wielu zmiennych $\mathrm{w}$ czasie i przestrzeni determinant. W artykule przybliżono wybrane aspekty teoretyczne i praktyczne problematyki determinant kształtowania polskiego bezpieczeństwa gospodarczego. Opisano istotę bezpieczeństwa gospodarczego. Przedstawiono pojęcie i rodzaje determinant tego bezpieczeństwa w ujęciu teoretycznym, w tym zaproponowano własną klasyfikację determinant bezpieczeństwa gospodarczego. Zwrócono uwagę na makroekonomiczne determinanty polskiego bezpieczeństwa gospodarczego. Przeanalizowano wyniki Narodowego Programu Foresight Polska $2020 \mathrm{w}$ aspekcie determinant kształtowania polskiego bezpieczeństwa gospodarczego. Zaprezentowano zapisy Strategii Bezpieczeństwa Narodowego RP dotyczące bezpieczeństwa gospodarczego.

\section{DETERMINANTS OF POLISH ECONOMIC SECURITY DEVELOPMENT. SELECTED ASPECTS}

\begin{abstract}
Condition for the development of modern states and societies is appropriate shaping of economic security. Effectiveness and efficiency of economic security development depend largely

19 Ibidem, s. 18.
\end{abstract}


on the rational identification and use of many determinants variable in space and time. This article introduces some selected aspects of theoretical and practical issues of determinants of Polish economic security shaping. The essence of economic security is described. The paper presents the concept and types of determinants of the security in theoretical approach, including own proposed classification of the economic security determinants. Attention is drawn at the macroeconomic determinants of Polish economic security. The results of the National Programme Foresight Poland 2020 is analysed in terms of the determinants of Polish economic security shaping. Provisions of the National Security Strategy of the Republic of Poland on economic security are presented. 
ANNA POTYRALA

\section{WSPÓŁPRACA PAŃSTW \\ Z MIĘDZYNARODOWYMI TRYBUNALAMI KARNYMI A SUWERENNOŚĆ.}

\section{STUDIUM POLITOLOGICZNO-PRAWNE}

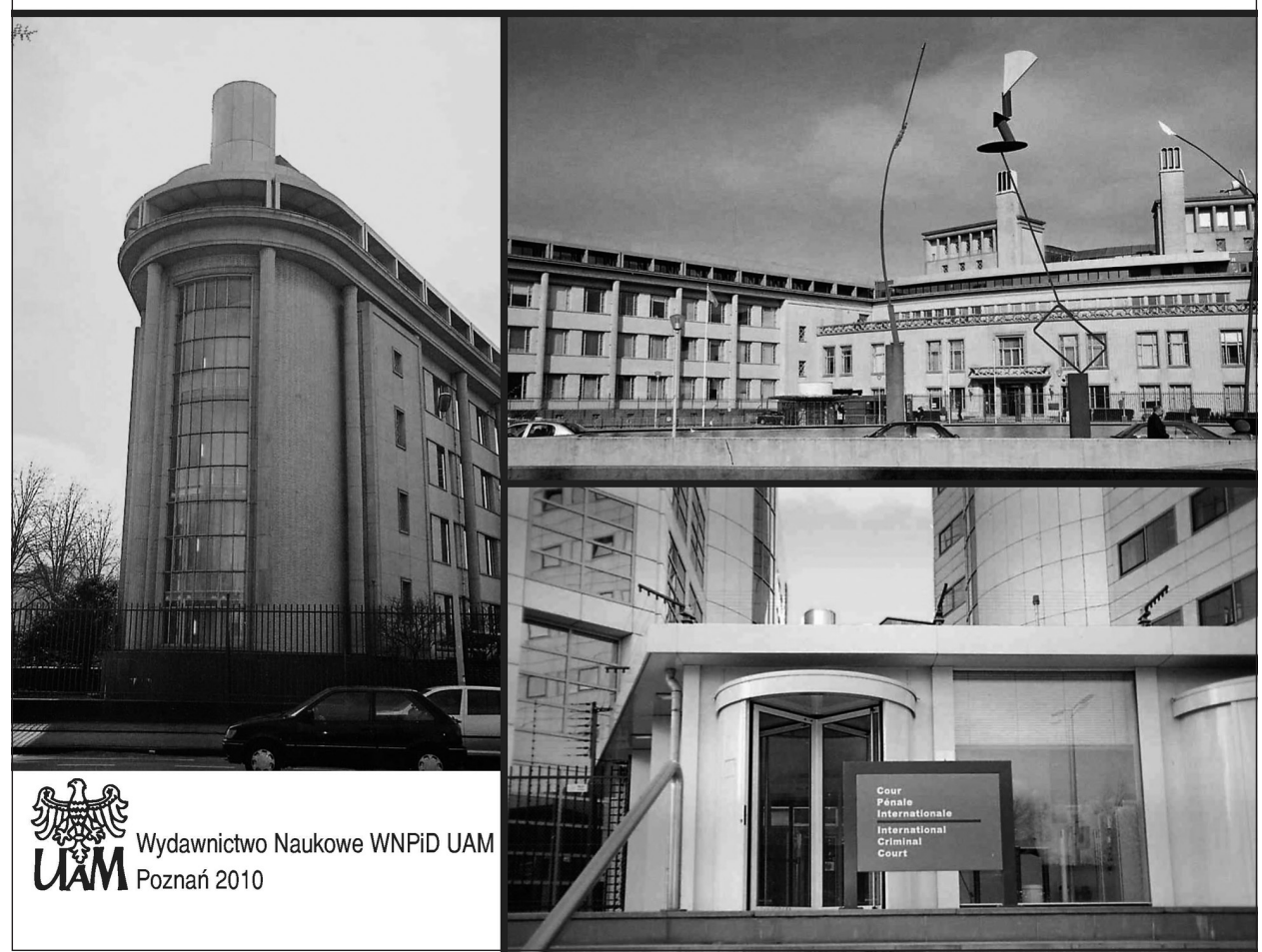


